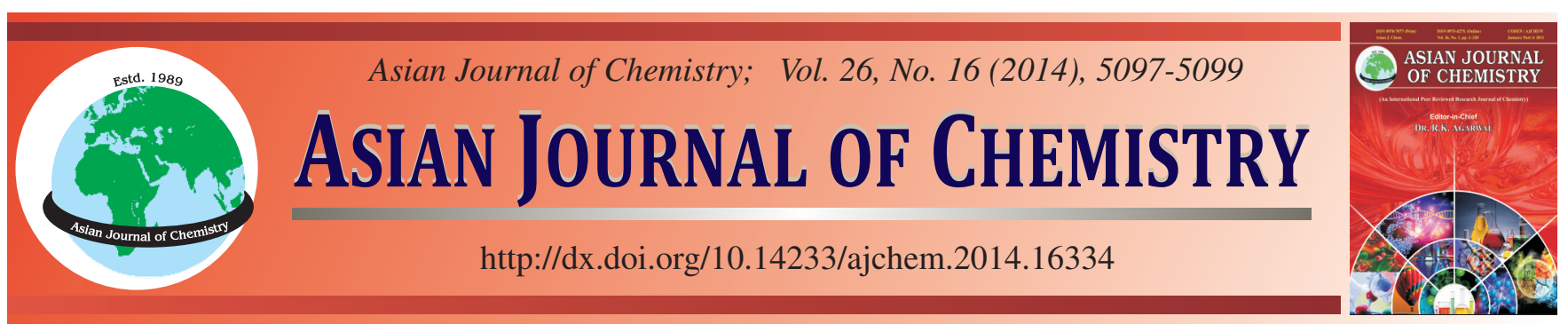

\title{
Determination of Antioxidant Compounds from Leaf and Stem of Angelica keiskei by Gas Chromatography-Mass Spectrometry
}

\author{
L.Q. Qin, S.Y. LuO, Z.H. Zhan, X.X. Liu" and K. WANG ${ }^{*}$
}

Department of Chemistry and Pharmacy, Guilin Normal College, Guilin 541001, P.R. China

*Corresponding authors: Fax: +86 77 32806321; Tel: +86 77 32823285; E-mail: lizhangdong2005@163.com, chemwang2006@aliyun.com

Keywords: Angelica keiskei, Antioxidant, Free radical scavenging activity, Gas chromatography-mass spectrometry.

\section{INTRODUCTION}

Free radical mediated reactions and reactive oxygen species are the major reasons in the pathological events such as aging, cancer, coronary heart ailment and Alzheimer's disease ${ }^{1}$. While the antioxidant defense mechanisms declined or exposure to environmental factors such as smoke, pollution, ultraviolet radiation, high-fat diet, etc. or under other pathological conditions, the levels of free radical and reactive oxygen species in living systems ascended, resulting in oxidative stress which can damage key organic substrates such as DNA, lipids and proteins, compromising cells physiological function thus led to pathological events ${ }^{2}$. So much attention has been focused on antioxidants which could protect the human body from oxidative damage by free radicals and reactive oxygen species. However, some synthetic antioxidants used in foods may accumulate in the body, resulting in liver damage and carcinogenesis $^{3}$, therefore the development and utilization of the safety antioxidant without toxicity are desired. With proved excellent free radical scavenging activities ${ }^{4}$, direct plant extracts or compounds from them are regards as good candidates to search for new antioxidant rather than synthetic ones.

Angelica keiskei is a perennial plant belonging to umbelliferae and has been taken as a health-promoting vegetable grown originally in Japan. Putative beneficial effects of Angelica keiskei reported including the antitumor, anti-metastatic activities ${ }^{5}$ and inhibition effects on hepatic lipid peroxide ${ }^{6}$. The most important compounds from Angelica keiskei is chalcones, which reported to have inhibition of IL- 6 production in TNF- $\alpha$-stimulated MG-63 cell ${ }^{7}$, antidiabetic activities ${ }^{8}$, cancer chemopreventive effects ${ }^{9}$, superoxide-scavenging activity ${ }^{10}$ and inhibition on influenza virus neuraminidase ${ }^{11}$. Moreover, there are some other kinds of bioactivies compounds isolated from Angelica keiskei, such as Ashitabaol $\mathrm{A}^{12}$, phytonutrients ${ }^{13}$. Recently, isobavachalcone, xanthoangelol and 4-hydroxyderricin were also isolated from the $95 \%$ ethanol extract of Angelica keiskei which have notable NQO1 induction activity ${ }^{14}$. However, the trace of antioxidant compounds from leaf extract and stem extract of Angelica keiskei has been seldom reported to the best of our knowledge. In order to elucidate the roles of antioxidant compounds in health-promoting functions of Angelica keiskei, in present study, the antioxidant activities of leaf extract and stem extract of Angelica keiskei were evaluated employing 2,2'-diphenyl-1-picrylhydrazyl radical scavenging assay, then GC-MS of leaf extract and stem extract was processed to determined mail antioxidant activities compounds.

\section{EXPERIMENTAL}

2,2'-Diphenyl-1-picrylhydrazyl was purchased from Sigma Chemicals Co. (St. Louis, MO, USA). Other chemicals were purchased from China National Medicine Group Shanghai Corporation (Shanghai, China). All chemicals and solvents used were of analytical grade.

The following instruments were used: UV-1100 spectrophotometer (Beijing Rayleigh Analytical Instrument Corporation, Beijing, China); RE-52AA rotavapour (Shanghai Yarong 
Biochemistry Instrument Factory, Shanghai, China); DZF-1B vacuum drier (Shanghai Yuejin Medical Instrument CO., Ltd., Shanghai, China); SHB- $\beta$ A water-circulation multifunction vacuum pump (Zhengzhou Great Wall Scientific Industry and Trade CO., Ltd., Zhengzhou, China). Agilent 6890-5973N GC/ MS (Agilent Technologies, Shanghai, China).

Preparation of extracts: Angelica keiskei was supplied by Guizhou biological characteristics technology company. The leaf and stem of Angelica keiskei were ground (max particle size $0.4 \mathrm{~mm}$ ) after dried in room temperature, then extracted $(100 \mathrm{~g})$ with methyl alcohol $(300 \mathrm{~mL}, 60 \%)$ with ultrasonic assisted extraction $(500 \mathrm{~W}, 100 \mathrm{MHz})$ at $40{ }^{\circ} \mathrm{C}$ for $40 \mathrm{~min}$ after soak for $12 \mathrm{~h}$. Subsequently, extract solution was filtered with Whatman No. 1 filter paper and then evaporated using a $\mathrm{RE}-52 \mathrm{AA}$ rotavapour at $35^{\circ} \mathrm{C}$ and a SHB- $\beta \mathrm{A}$ water-circulation multifunction vacuum pump. Extracts were finally dried in a DZF-1B vacuum drier at $30^{\circ} \mathrm{C}$ and $0.07 \mathrm{MPa}$. The dried sample of each extract was weighted to determin the yields and stored in a freezer until use. The yield of leaf extract and stem extract was 8.64 and $9.33 \%$, respectively.

Scavenging activity on 2,2'-diphenyl-1-picrylhydrazyl free radical: To evaluate the free radical scavenging activity, leaf extract and stem extract were allowed to react with a stable free radical, 2,2'-diphenyl-1-picrylhydrazyl radical compared to rutin. Briefly, samples solution $(0.1 \mathrm{~mL})$ in distilled water at different concentrations $(0.2,0.5,0.8,1.2 \mathrm{mg} / \mathrm{mL})$ was added to $3.9 \mathrm{~mL} 0.004 \%(\mathrm{w} / \mathrm{v})$ solution of DPPH in ethanol. The reaction mixture was incubated at room temperature. The scavenging activity on DPPH radical was determined by measuring the absorbance at $517 \mathrm{~nm}$ after $0.5 \mathrm{~h}$. The antioxidant activity was expressed as a percentage of scavenging activity on DPPH radical: SC \% = [1-(absorbance of sample)/ (absorbance of control) $] \times 100 \%$. The control contains all reagents except the extract.

Analysis of GC/MS: Analyses were performed with a Agilent 6890-5973N GC/MS. Chromatographic condition are below: HP-5MS $30 \mathrm{~m} \times 0.25 \mathrm{~mm} \times 0.25 \mu \mathrm{m}$ quartz flexibility capillary column, initial column temperature is $50^{\circ} \mathrm{C}$, keep warm for $2 \mathrm{~min}$, then heat to $260^{\circ} \mathrm{C}$ by $10^{\circ} \mathrm{C} / \mathrm{min}^{-1}$. Injection port's temperature is $260^{\circ} \mathrm{C}$, carrier gas flow rate is $1 \mathrm{~mL} / \mathrm{min}$, the way inject simple into it is splitless. MS with electronimpact (EI) ionization (electron energy, $70 \mathrm{eV}$ ) was performed in the selected ion monitoring (SIM) mode. Mass spectrometry conditions are: Electronic multiplier voltage $1.42 \mathrm{~V}$, EI source electronic energy for $70 \mathrm{eV}$, ion source temperature of $200{ }^{\circ} \mathrm{C}$, scanning time interval $0.43 \mathrm{~s}$, quality scanning range $(\mathrm{m} / \mathrm{z})$ 40-600 amu.

\section{RESULTS AND DISCUSSION}

Antioxidant activities, especially radical scavenging activity, are very important due to the deleterious role of free radicals in foods and in biological system. In present assay, a concentration-dependent 2,2'-diphenyl-1-picrylhydrazyl radical scavenging assay was carried out with leaf extract and stem extract comparing to rutin. The results are normalized and expressed as $\mathrm{EC}_{50}$ values ( $\mu \mathrm{g}$ various extracts per $\mathrm{mL}$ ) for comparison. Effectiveness of antioxidant properties are inversely correlated with their $\mathrm{EC}_{50}$ values. Fig. 1 illustrates that radical

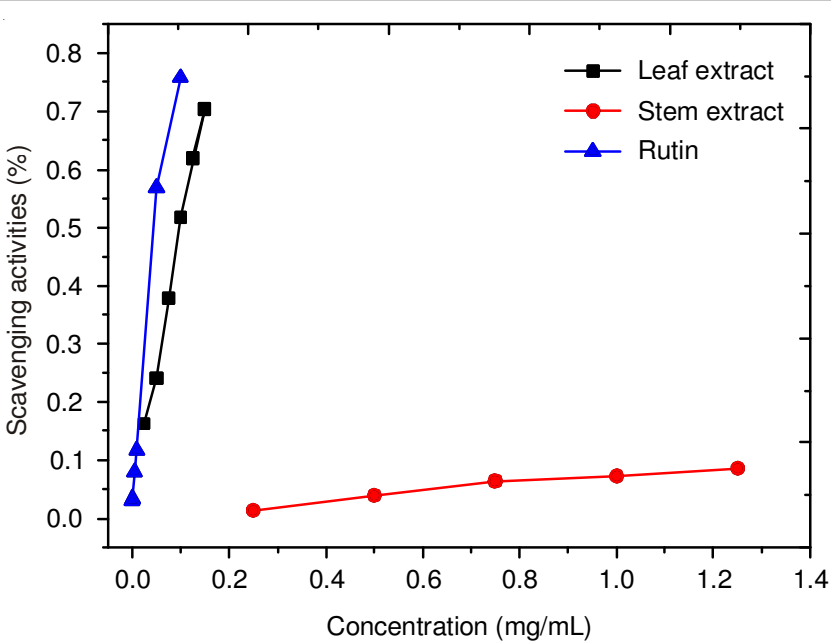

Fig. 1. 2,2'-Diphenyl-1-picrylhydrazyl (DPPH) free radical scavenging activities of rutin, leaf extract and stem extract

scavenging activities of leaf extract and stem extract increased with increasing concentration. The $\mathrm{EC}_{50}$ values of leaf extract was $0.10 \mathrm{mg} / \mathrm{mL}$ which was close to rutin with $\mathrm{EC}_{50}$ values was $0.06 \mathrm{mg} / \mathrm{mL}$, indicating excellent DPPH radical scavenging activity. However, the DPPH radical scavenging activity of stem extract was not so good with the $\mathrm{EC}_{50}$ only $7.08 \mathrm{mg} / \mathrm{mL}$.

In order to identify free radical scavenging activities compounds in leaf extract and stem extract, GC-MS were performed. The retention time and the relative content of each compound contained in leaf extract and stem extract are given in Tables 1 and 2, respectively. With the assistance of the NIST's pesticide library, 10 compounds (a-j) were identified from leaf extract with the total peak area of $61.22 \%$ and the most high relative content $\%$ of (E)-3,7,11,15-tetramethylhexadec-2-en1-ol (i) reach to $19.87 \%$. For stem extract, compounds 3,5dihydroxy-6-methyl-2H-pyran-4(3H)-one (c) and 2-dimethyl8-oxo-2,3,4,8-tetrahydropyrano[3,2-g]chromen-3-yl-3methylbut-2,3-noate (j) were indentified which also present in leaf extract with the total peak area of $67.59 \%$. The relative content $\%$ of compounds $\mathbf{c}$ and $\mathbf{j}$ in stem extract was 31.75 and $1.86 \%$, respectively.

As shown in Fig. 2, the structures of these compounds from leaf extract and stem extract include furan, pyran, coumarin, fatty acid/ester and unsaturated fatty acid/ester. It should be noted that compound $\mathbf{c}$ was reported to be a strong antioxidant recently which should contribute to the antioxidant activities of stem extract and leaf extract ${ }^{15}$. Interestingly, the antioxidant activity of stem extract was not so good as leaf extract although the relative relative content $\%$ of compound c in stem extract reach to $31.75 \%$ which is much higher than that in leaf extract. This might due to the synergistic or antagonism effect of compound $\mathbf{c}$ with other compounds. In addition, fatty acid/ester and unsaturated fatty acid/ester should also play important roles because they have been proved to exhibit antioxidant potential in other antioxidant plants ${ }^{16}$.

\section{Conclusion}

In conclusion, the leaf extract of Angelica keiskei exhibits excellent antioxidant potential which is close to that of rutin but better than stem extract. Therefore, Angelica keiskei could 
<smiles>OCc1ccco1</smiles>

a<smiles>O=C1CCCO1</smiles>

b<smiles>CC1=C(O)C(=O)C(O)CO1</smiles>

c<smiles>OCC1CCC(CO)O1</smiles>

d<smiles>COc1cc2ccc(=O)oc2c2ccoc12</smiles>

g<smiles>CC(C)=CC(=O)OC1Cc2cc3ccc(=O)oc3cc2OC1(C)C</smiles>

j<smiles>CCCCCCCCCCCCCCCC(=O)OC</smiles><smiles>CC/C=C/C/C=C/C/C=C/CCCCCCCC(=O)OC</smiles><smiles>CCCCCCCCCCCCCCCC(=O)O</smiles><smiles>[3H]</smiles><smiles>CC(=CCO)CCCC(C)CCCC(C)CCCC(C)C</smiles>

Fig. 2. Compounds from Angelica keiskei's leaf and stem identified by GC-MS

PEAKS IDENTIFIED IN THE MASS SPECTRAL CHROMATOGRAMS OF LEAFEXTRACT SAMPLES

\begin{tabular}{|c|c|c|c|}
\hline $\begin{array}{l}\text { Peak } \\
\text { No. }\end{array}$ & $\begin{array}{l}\text { Retention } \\
\text { time (min) }\end{array}$ & Name of compounds & $\begin{array}{l}\text { Relative } \\
\text { content } \\
(\%)\end{array}$ \\
\hline 1 & 3.664 & a: Furan-2-ylmethanol & 3.92 \\
\hline 2 & 4.075 & b: Dihy drof uran-2(3H)-one & 2.33 \\
\hline 3 & 8.813 & $\begin{array}{c}\text { c: 3,5-Dihydroxy-6-mehtyl-2H- } \\
\text { pyran-4(3H)-one }\end{array}$ & 8.54 \\
\hline 4 & 10.433 & $\begin{array}{l}\text { d: (Hydroxy methyl)tetrahydrofuran- } \\
\text { 2-carbaldehyde }\end{array}$ & 7.58 \\
\hline 5 & 21.248 & e: Methyl palmitate & 1.18 \\
\hline 6 & 21.694 & f: Palmitic acid & 2.66 \\
\hline 7 & 22.079 & $\begin{array}{l}\text { g: 6-Methoxy-2H-furo[2,3- } h]- \\
\text { chromen-2-one }\end{array}$ & 2.72 \\
\hline 8 & 23.316 & $\begin{array}{c}\text { h: }(9 E, 12 E, 15 E) \text {-Methyl octadeca- } \\
9,12,15 \text {-trienoate }\end{array}$ & 11.19 \\
\hline 9 & 23.598 & $\begin{array}{l}\text { i: (E)-3,7,11,15-tetramethylhexadec- } \\
\text { 2-en-1-ol }\end{array}$ & 19.87 \\
\hline 10 & 28.14 & $\begin{array}{l}\text { j: 2-Dimethyl-8-oxo-2,3,4,8- } \\
\text { tetrahydropyrano[3,2-g]chromen-3- } \\
\text { yl-3-methylbut-2,3-noate }\end{array}$ & 1.23 \\
\hline
\end{tabular}

Peak area normalization method determine the component relative content, all the peak area as $100 \%$, the total content of substance was $61.22 \%$

\section{TABLE-2}

PEAKS IDENTIFIED IN THE MASS SPECTRAL CHROMATOGRAMS OF STEM EXTRACT SAMPLES

\begin{tabular}{|c|c|c|c|}
\hline $\begin{array}{c}\text { Peak } \\
\text { no. }\end{array}$ & $\begin{array}{l}\text { Retention } \\
\text { time (min) }\end{array}$ & Name of compounds & $\begin{array}{c}\text { Relative } \\
\text { content }(\%)\end{array}$ \\
\hline 1 & 8.90 & $\begin{array}{c}\text { c: 3,5-dihydroxy-6-mehtyl- } 2 H \text { - } \\
\text { pyran-4(3H)-one }\end{array}$ & 31.75 \\
\hline 2 & 28.14 & $\begin{array}{l}\text { j: 2,2-dimethyl-8-oxo-2,3,4,8- } \\
\text { tetrahydropyrano[3, 2-g]- chromen- } \\
\text { 3-yl-3-methylbut-2-3noate }\end{array}$ & 1.86 \\
\hline
\end{tabular}

The peak area normalization method determine the component relative content, all the peak area as $100 \%$, the total content of substance was $33.61 \%$

be used as a readily accessible source of the natural antioxidant in food and pharmaceutical industry. GC-MC analysis indicated that the mail antioxidant activities compounds in leaf extract were 3,5-dihydroxy-6-methyl-2H-pyran-4(3H)-one, fatty acid/ester and unsaturated fatty acid/ester. Moreover, 3,5dihydroxy-6-methyl- $2 H$-pyran-4(3H)-one was also determined in stem extract. These results provide an useful information for the further isolation of antioxidant active compounds from Angelica keiskei.

\section{ACKNOWLEDGEMENTS}

This study was supported by Guangxi Universities Scientific Research Project (201203YB180, 201203YB181 and 200103YB159) and The Scientific Research and Technological Development Project of Guilin (No. 20110106-2, 20130103-6).

\section{REFERENCES}

1. K. Arunachalam and R.A.J. Appadorai, Free Radic. Antioxid., 3, 47 (2013).

2. J. Nordberg and E.S.J. Arnér, Free Radic. Biol. Med., 31, 1287 (2001).

3. L. Sun, J. Zhang, X. Lu, L. Zhang and Y. Zhang, Food Chem. Toxicol., 49, 2689 (2011).

4. S.A. Marathe, V. Rajalakshmi, S.N. Jamdar and A. Sharma, Food Chem. Toxicol., 49, 2005 (2011).

5. Y. Kimura and K. Baba, Int. J. Cancer, 106, 429 (2003).

6. J.C. Park, J.G. Park, H.J. Kim, J.M. Hur, J.H. Lee, N.J. Sung, S.K. Chung and J.W. Choi, Phytother. Res., 16(S1), 24 (2002).

7. J.E. Shin, E.J. Choi, Q. Jin, H.G. Jin and E.R. Woo, Arch. Pharm. Res., 34, 437 (2011).

8. T. Enoki, H. Ohnogi, K. Nagamine, Y. Kudo, K. Sugiyama, M. Tanabe, E. Kobayashi, H. Sagawa and I. Kato, J. Agric. Food Chem., 55, 6013 (2007).

9. T. Akihisa, H. Tokuda, D. Hasegawa, M. Ukiya, Y. Kimura, F. Enjo, T. Suzuki and H. Nishino, J. Nat. Prod., 69, 38 (2006).

10. N. Aoki, M. Muko, E. Ohta and S. Ohta, J. Nat. Prod., 71, 1308 (2008).

11. J.Y. Park, H.J. Jeong, Y.M. Kim, S.J. Park, M.C. Rho, K.H. Park, Y.B. Ryu and W.S. Lee, Bioorg. Med. Chem. Lett., 21, 5602 (2011).

12. N. Aoki and S. Ohta, Tetrahedron Lett., 51, 3449 (2010).

13. L. Li, G. Aldini, M. Carini, C.Y.O. Chen, H.-K. Chun, S.-M. Cho, K.-M. Park, C.R. Correa, R.M. Russell, J.B. Blumberg and K.-J. Yeum, Food Chem., 115, 227 (2009).

14. L. Luo, R. Wang, X. Wang, Z. Ma and N. Li, Food Chem., 131, 992 (2012).

15. X. Yu, M. Zhao, F. Liu, S. Zeng and J. Hu, Food Res. Int., 51, 397 (2013).

16. (a) A. Aktumsek, G. Zengin, G.O. Guler, Y.S. Cakmak and A. Duran, Food Chem., 141, 91 (2013); (b) N. Beeharry, J.E. Lowe, A.R. Hernandez, J.A. Chambers, F. Fucassi, P.J. Cragg, M.H.L. Green and I.C. Green, Mutat. Res.-Fund. Molecul. Mechan. Mutagen., 530, 27 (2003). 